\title{
INFLUENCE OF THE F-34 UNIFIED BATTLEFIELD FUEL WITH BIO COMPONENTS ON USABLE PARAMETERS OF THE IC ENGINE
}

\section{WPŁYW MIESZANIN JEDNOLITEGO PALIWA POLA WALKI F-34 Z BIOKOMPONENTAMI NA PARAMETRY UŻYTECZNE SILNIKA*}

\begin{abstract}
The problem of the military vehicles engines fuelling increases with the growth of the amount of vehicles in the armies. At the same time, another problem with fuel supply in modern engines is the use of bio component additives, which changes characteristics (quality) of the used fuels. Therefore, it is important to take actions to adapt engines to powering with fuels coming from renewable sources. The aim of the research was to define the influence of an engine supplying fuel on work parameters and exhaust gases composition in the G9T Renault diesel engine. The tests were conducted during fuelling of the engine with six kinds of fuels: basic fuel (diesel oil), NATO code F-34 fuel, as well as fuel mixtures: F-34 and RME with different ratio. In the result of the research it was concluded that the parameters of the G9T Renault engine with the common rail fuel system in terms of F-34 and RME consumption (using) decreased in comparison to diesel oil basic fuel.
\end{abstract}

Keywords: IC engine, fuel supply system, F-34 fuel, RME-Rapeseed Methyl Esters.

\begin{abstract}
Problemy zasilania silników pojazdów wojskowych narastaja wraz ze wzrostem liczby pojazdów w armiach. Silniki tlokowe i turbinowe wykorzystuja paliwa różniące się zakresem temperatury destylacji. Dodatkowym problemem przy zasilaniu współczesnych silników spalinowych jest konieczność stosowania biokomponentów, które moga zmieniać właściwości paliw podstawowych $i$ wptywać na pogorszenie przebiegu spalania. Dlatego też konieczne jest podejmowanie działań prowadzacych do zbadania wptywu paliw pochodzacych ze źródeł odnawialnych na parametry pracy silników. Celem badań było ocena wpływu zastosowanego paliwa na parametry użyteczne i skład spalin tłokowego silnika o zapłonie samoczynnym Renault G9T. Badania przeprowadzono podczas zasilania silnika sześcioma rodzajami paliwa: paliwem podstawowym, jakim byt olej napędowy, paliwem lotniczym o kodzie NATO F-34, mieszaninami paliw: F-34 i estrów metylowych wyższych kwasów tluszczowych oleju rzepakowego. W wyniku przeprowadzonych badań stwierdzono, że parametry silnika Renault G9T z wysokociśnieniowym układem wtrysku, zasilanego paliwem F-34 i biokomponentami uległy pogorszeniu w stosunku do podstawowego paliwa, jakim był olej napędowy, co może mieć znaczenie przy wykorzystaniu tego rodzaju paliw w silnikach pojazdów wojskowych.
\end{abstract}

Slowa kluczowe: silnik spalinowy, układ zasilania, paliwo F-34, RME-estry metylowe kwasów oleju rzepakowego.

\section{Introduction}

Liquid fuels are the most important source of energy on modern battlefield. Availability of fuels decides about mobility of the army, effectiveness of weapons or other support equipment and delivery of needed amount of supplies. Realisation of increasing requirements of fighting troops in fuels or lubrication oils is one of the most important problems of logistic supplying of a battlefield. It is calculated, that mean use of fuel and lubrication oil may reach $30 \mathrm{~kg}$ per one soldier per day $[4,11]$. The delivery of such a big quantity of supplies to the army, in terms of enemy interaction on communication systems and supplying infrastructure is an enormous sophisticated problem. It is why there is a trend to standardize all sorts of fuels in the army. For instance NATO introduced F-34 unified fuel for battlefield. As the effect it was decided to unify fuels for reciprocating and turbine internal combustion engines used in land vehicles and on land operating planes. Fuels known as F-34/35 were introduced. It has the same base components as plane fuel JP8 (JET-A1). It's final quality is the effect of using additive components added to the base fuel before final distribution of fuel to a vehicle's tank.

Nowadays the F-34/35 fuel is taken as unified battlefield fuel for all diesel engines of NATO nations. At the end of 20th century the
F-34 fuel was taken under investigation, which focused mainly about elder generation engines completed with in-line and rotation injection pumps [2], without engines with high pressure Common rail systems. From the time of introduction that fuel the injection equipment has changed. In-line injection pumps with plungers and barrels injection units are used very rarely. Common Rail and unit injection systems are used instead. In that system injection pressure reaches $140 \div 200$ MPa. It has a significant change on fuel quantity during injection [7, $8,10,13,14]$. Terms condition of fuel before injection to combustion chamber are changed relevantly, and temperature is much higher in comparison to classical in-line injection pump.

The Common Rail systems are commonly used in engines of cars, low duty and heavy duty trucks, locomotives and vessels as well as combat vehicles, for instance the MTU engines of MT 880 series. In these engines in-line pumps used in earlier version were replaced by CR systems. That systems are widely used in heavy duty trucks, which are in possession of Polish Army (MAN, IVECO).

Using raw F-34 fuel to fuel engine equipped with Common Rail system may cause serious change of work parameters. Own investigation of the G9T engine equipped with CR fuelling system led in Military University of Technology $[10,11]$ shows important diminish of

$\overline{(*)}$ Tekst artykułu w polskiej wersji językowej dostępny w elektronicznym wydaniu kwartalnika na stronie www.ein.org.pl 
maximum torque and $\mathrm{NO}_{\mathrm{x}}$ in exhaust gases and increasing of specific fuel consumption.

Table 1. Chosen characteristics of fuels used during investigation [3, 11]

\begin{tabular}{|c|c|c|c|c|}
\hline Quantity & Unit & $\begin{array}{c}\text { ON IZ-40 } \\
\text { fuel }\end{array}$ & RME fuel & F-34 fuel \\
\hline Density in temp. $15^{\circ} \mathrm{C}$ & $\mathrm{g} / \mathrm{cm}^{3}$ & 0,831 & 0,881 & 0,804 \\
\hline Heat value & $\mathrm{MJ} / \mathrm{kg}$ & 43,2 & 38,3 & 42,8 \\
\hline Temperature of ignition & ${ }^{\circ} \mathrm{C}$ & 66 & 177 & 57 \\
\hline Temp. of cold filter block & ${ }^{\circ} \mathrm{C}$ & -31 & -9 & -54 \\
\hline Kinematic viscosity in $40^{\circ} \mathrm{C}$ & $\mathrm{mm}^{2} / \mathrm{s}$ & 2,35 & 4,60 & 1,27 \\
\hline Sulphur ratio & $\mathrm{mg} / \mathrm{kg}$ & 350 & 19 & 3000 \\
\hline Cetane number & - & 50 & 43 & 45 \\
\hline \hline
\end{tabular}

The F-34/35 fuels in compare to diesel oil are characterised by better characteristic in low temperature, less viscosity, less cetan number, less heat value. Technical advantage of unified fuel is: compatibility to aircraft fuel (JET-A1), less sensibility on biological contamination, availability on airports all over the world, better low-temperature characteristic, less possibility of flare/self-ignition in comparison to wide fraction hydrocarbons fuels, less emission of toxic components. Logistic advantages are supplying only one sort of fuel in the whole army, simplification of supply chain and unification of storehouses and storing facilities.

Disadvantages of the unified fuel are increasing needs and demands for fuels based on kerosene and diminish of demands for other fuels. It may cause increasing of a fuel price, diminish of an engine power connected with less heat value of kerosene, needs for modernization of currently used equipment and using fuel additives.

Using of fuels which consist of renewable components such as rapeseed methyl esters (RME) may cause shortening of supply chains. The reason is using local source of a rapeseed from nearby grain elevators which are spread on over the country. The only demand is to introduce an installation for rapeseed oil pressing and for it esterification in the army. Then the vulnerability of the army for fluctuation of supply smoothness in case of a military conflict.

"Ester" fuels are fundamentally different form hydrocarbon fuels by physicochemical characteristics. That is why in case of mixing it the final product parameters are changed. Changing of physicochemical characteristic is also connected to change of an engine work parameters [15]. Presented in different publications results of RME application in a pure form and as a mixture with diesel oil for compression ignition (CI) engines feeding are mainly similar, but the results of investigation where a mixture of RME and F-34 is used are not published. Investigation led on different engines with different combustion systems and an effective power and speed of rotation shows that bio component additive in diesel fuel influences on engine effective powers causing $5 \div 15 \%$ diminish of rotational speed in all range, and significant, ca. $15 \%$, increase of fuel consumption [1, 4 , $5,9,14]$.

Fuel which consists of RME has a little bit different characteristics then hydrocarbons fuels. It depends on different composition, because in molecule structure apart from a carbon and a hydrogen there is a quite big dose of an oxygen (ca.12\%). An oxygen ratio and unsaturated bindings conduced to auto ignition and complete combustion. An oxygen contained in fuel has more reactivity then an oxygen consisted in the air, it increase of a cetan number of that fuel. Changing of combustion process has positive influence concentration of toxic components and diminishes a smoke emission. Disadvantage of RME is large amount of water and aggressive influence on rubber parts and film-coating lacquer. $[6,9,12]$. That fuel has more density and viscos- ity, that its addition to standard F-34 fuel should cause the approach of the F-34 fuel attributes to diesel oil characteristic.

\section{Aim and range of work}

Current fuel situation in the world and predicted diminishing of natural sources of oil compel to searching for new kinds of fuels. It concerns fuels used to feed of military vehicles as well. Despite that the F-34 fuel was taken by NATO nations as basic fuel, there is very seriously considered the situation that will force to renew this fuel with other, even bio products. In the same time it is noticeable that increasing number of vehicles in military units which are powered by diesel engines equipped with the Common Rail systems and pump injection systems. Regardless of the method of high pressure injection of fuel the basic problems are the phenomena which occur during injection with high pressure of fuel and a fuel mixture creation and combustion processes.

The aim of presented results of investigation was the empiric evaluation of the F-34 fuel and its mixtures with bio rapeseed methyl esters components (RME) influence on parameters of a diesel engine equipped with high pressure injection system on example of Common Rail (CR) system.

\section{Object, methodises and range of investigation}

The object of investigation was a four cylinder Reanault G9T diesel engine with $95 \mathrm{~kW}$ effective power with rotational speed $\mathrm{n}=2500$ $\mathrm{rpm}$ and $280 \mathrm{~N}^{*} \mathrm{~m}$ torque with rotational speed $\mathrm{n}=1750 \mathrm{rpm}$, used in propulsion systems of light duty vehicles (LDV) of different producers. This is an engine with direct injection system equipped with a high pressure CR injection system. The engine is turbocharged and equipped with charged air cooling system (intercooler).

The engine was equipped by producer (in factory) with CR fuelling system by Bosch, which consists of following components:

- the EDC 15A53 controller (for service),

- the CR/CP1S3/L70/10-1S high pressure fuel pump,

- the BX CRI 1 electromagnetic injectors.

The range of investigation consisted of the engine effective parameters, parameters of combustion process and composition of exhaust gases measure. The investigation was led for all the engine work field (speed characteristic and series of load characteristics in all range of rotational speed of the engine). The investigation of load characteristics was led as a method of passive experiment in steady state of the engine work with rotational speed: $1500 \mathrm{rpm}, 2000 \mathrm{rpm}$, $2500 \mathrm{rpm}, 3000 \mathrm{rpm}$ and $3500 \mathrm{rpm}$. The external speed characteristic was done as well in range of $1000 \div 3750 \mathrm{rpm}$ with $250 \mathrm{rpm}$ step. The load characteristics were done by changing load in range from minimum (the idle speed) to maximum (on the external speed characteristic) with $30 \mathrm{~N}^{*} \mathrm{~m}$ step. During investigation the same quantities of load was set. It created the possibility to compare effective parameters of the engine in the same measuring points.

During investigation effective parameters of the engine, temperature (cooling liquid, lubrication oil, exhaust gases before and after turbocharger), concentration of: carbon dioxide, oxygen, carbon monoxide, hydrocarbons, nitrogen oxides, and smoke measured as extinction of radiation absorbed by exhaust gases.

The investigation was led on a standard dynamometer stand. The engine was load by the Schenck W-230 dynamometer with $230 \mathrm{~kW}$ maximum power. Torque produced by dynamometer was measured with tensometric transducer. Rotational speed was measured with pulse transducer in cooperation with toothed wheel which was on a dynamometer flange. Measuring of fuel consumption was led with AVL Fuel Balance weightmeter every $5 \mathrm{~s}$. Air flow by intercooler was done by two electric fans. Temperature of cooling liquid was controlled on the level $85 \div 90^{\circ} \mathrm{C}$ with use of an external heat exchanger. 
Table 2. List of investigation equipment used during investigation

\begin{tabular}{|c|c|c|c|c|}
\hline No. & Name of device / measured quantity & Type & Range & Accuracy \\
\hline 1. & $\begin{array}{l}\text { Eddy current brake } \\
\text { torque }-M_{o^{\prime}} \\
\text { rotated speed }-\mathrm{n}\end{array}$ & $\begin{array}{l}\text { Eddy current, } \\
\text { Schenck W } 230\end{array}$ & $\begin{array}{l}M_{o}=(0 \div 700) N^{*} m \\
n=(0 \div 4000) r p m\end{array}$ & $\begin{array}{l} \pm 0,1 \mathrm{~N} * \mathrm{~m} \\
\pm 1 \mathrm{rpm}\end{array}$ \\
\hline 2. & Fuel weight-meter, fuel consumption $-G_{e}$ & AVL 733S Fuel Balance & $(0 \div 200) \mathrm{kg} / \mathrm{h}$ & $\pm 0.005 \mathrm{~kg} / \mathrm{h}$ \\
\hline 3. & $\begin{array}{l}\text { Exhaust analyser - measuring of toxic elements con- } \\
\text { centration in exhaust gases } \\
\text { carbon dioxide }\left(\mathrm{CO}_{2}\right), \\
\text { hydrocarbons }(\mathrm{HC}) \\
\text { carbon monoxide }(\mathrm{CO}), \\
\text { nitrogen oxides }\left(\mathrm{NO}_{x}\right), \\
\text { oxygen }\left(\mathrm{O}_{2}\right)\end{array}$ & AVL CEBII & $\begin{array}{c}\mathrm{CO}_{2}(0,01 \div 23) \% \\
\mathrm{HC}(1,0 \div 2200) \mathrm{ppm} \\
\mathrm{CO}(1,0 \div 11000) \mathrm{ppm} \\
\mathrm{NO}_{\times}(1,0 \div 6000) \mathrm{ppm} \\
\mathrm{O}_{2}(0,1 \div 21) \%\end{array}$ & $\begin{array}{l} \pm 0,1 \% \text { measured } \\
\quad \text { quantity }\end{array}$ \\
\hline 4. & $\begin{array}{l}\text { Smoke concentration - extinction coefficient of light } \\
\text { radiation }-k \text {. }\end{array}$ & AVL Opacimeter 4390 & $(0.001 \div 10.0) \mathrm{m}^{-1}$ & $\pm 0.002 \mathrm{~m}^{-1}$ \\
\hline 5. & Thermocouple - measuring of exhaust temperature $-\mathrm{T}$ & $\mathrm{NiCr}-\mathrm{NiAl}(\mathrm{K})$ & $(-50 \div 1100)^{\circ} \mathrm{C}$ & $\pm 1^{\circ} \mathrm{C}$ \\
\hline
\end{tabular}

Results of engine parameters measuring were gathered during all experiment. The purpose was current observation of a technical state or reveal of the engine possible malfunction circumstances and observation of next steps of investigation. The results of the engine effective parameters measuring were calculated back to normal atmospheric condition according to PN-ISO 15550:2009 standard.

During the investigation the engine was fuelled with fuels:

- diesel oil IZ-40 - in the paper it is signed as ON,

- F-34/35 fuel - in the paper it is signed as F-34,

a)

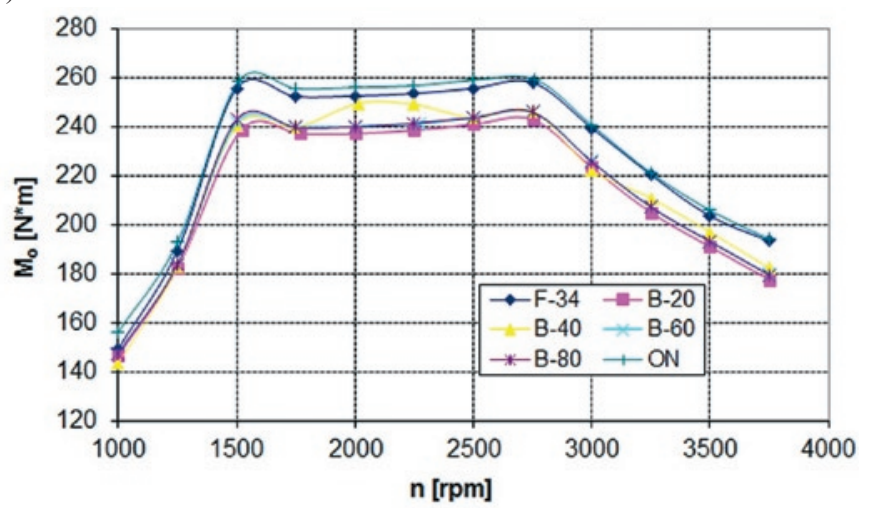

c)

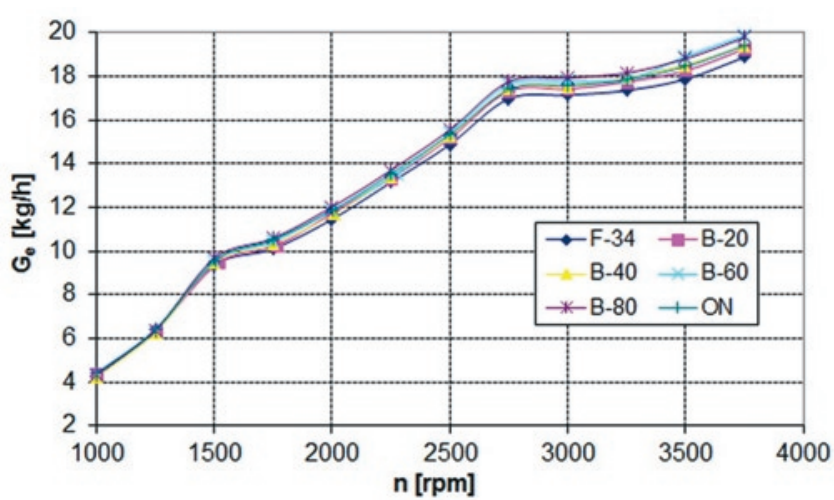

- mixtures of the F-34/35 fuel and RME - in the paper it is signed as B-20, B-40, B-60 and B- 80 where the number following letter $\mathrm{B}$ stands for a weight ratio of RME in the mixture.

\section{Results of investigation}

\subsection{The external characteristic of the engine}

The analysis of investigation results lets to evaluate the different kinds of fuels influence on the engine effective parameters, indi-

b)

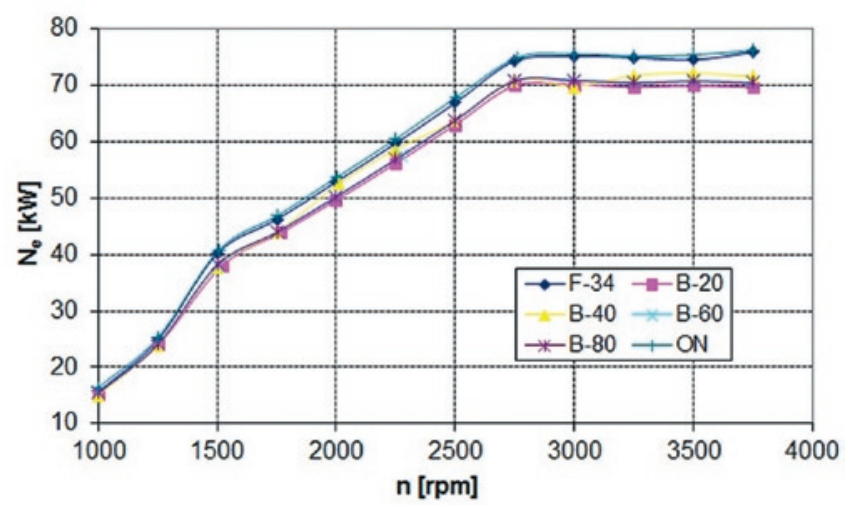

d)

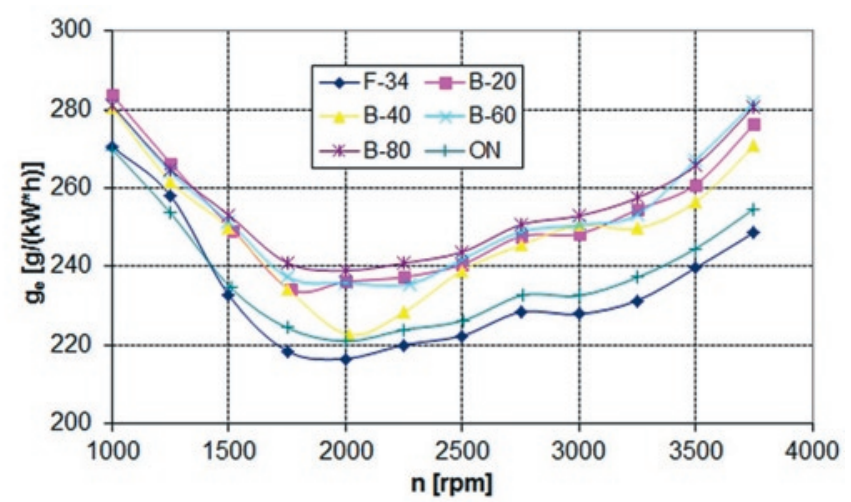

Fig. 1. External characteristic of the engine: a) torque, b) effective power, c) fuel consumption, d) specific fuel consumption. 
a)

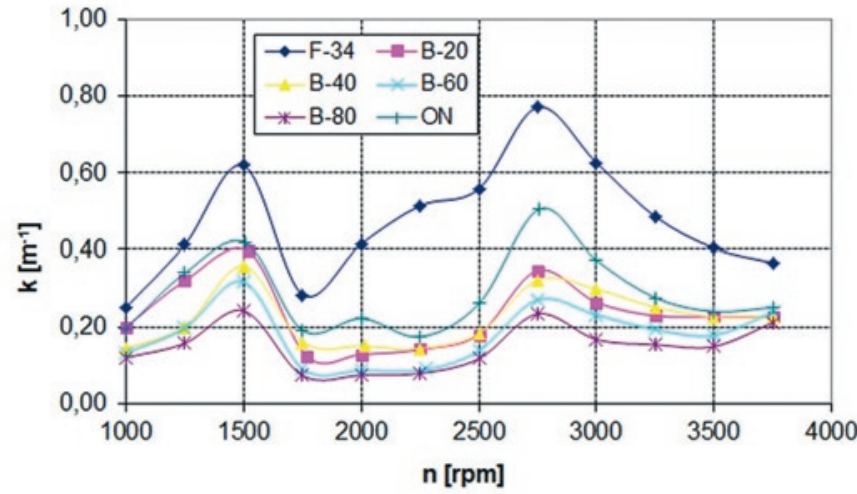

c)

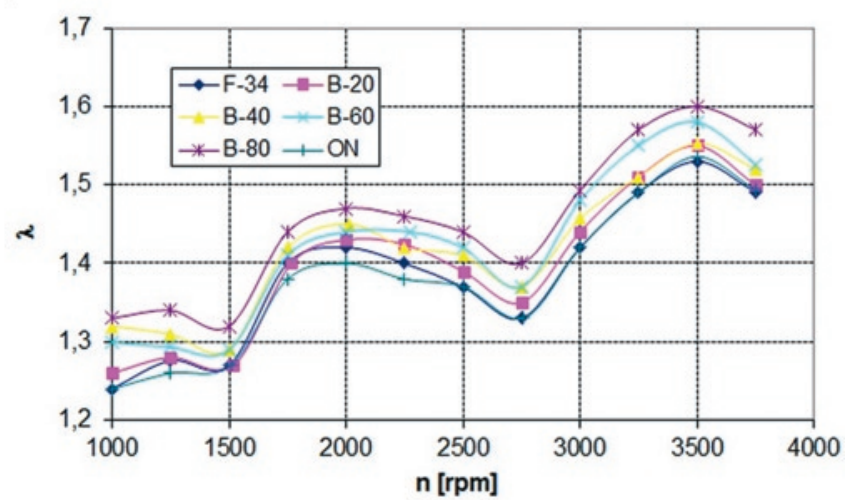

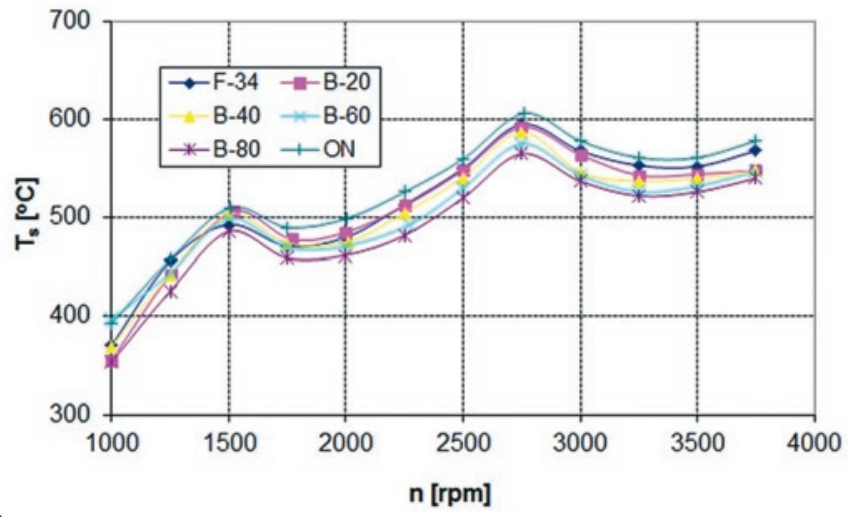

d)

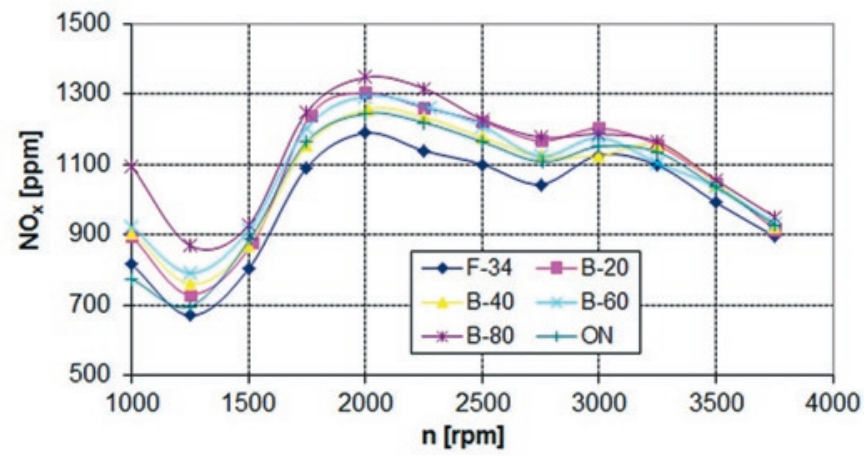

Fig. 2. External characteristic of the engine: a) extinction coefficient of absorbed radiation, b) temperature of exhaust gases, c) air/fuel ratio coefficient, d) concentration of nitrogen oxides in exhaust

a)

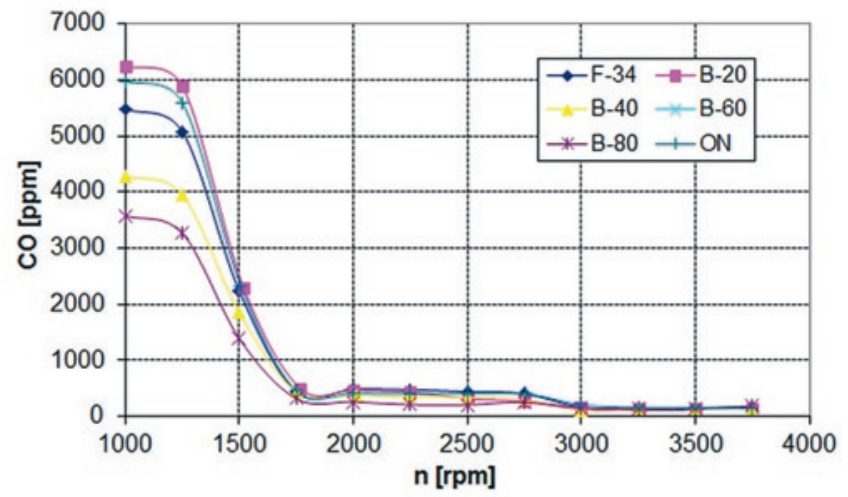

c)

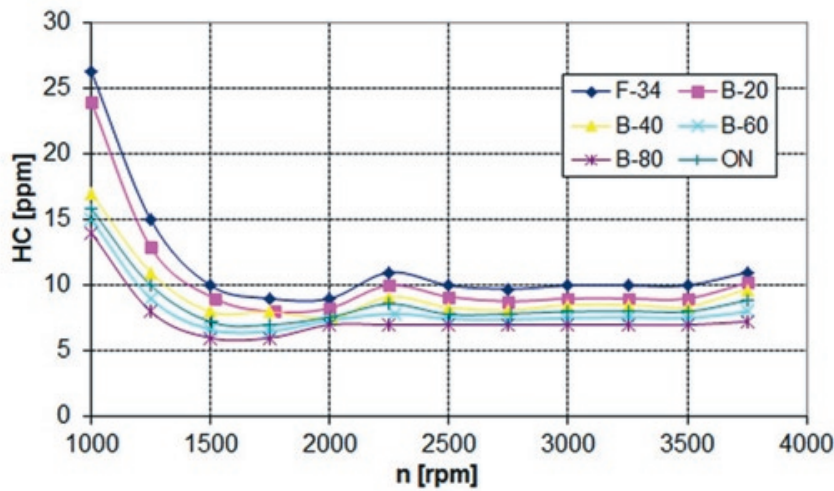

b)

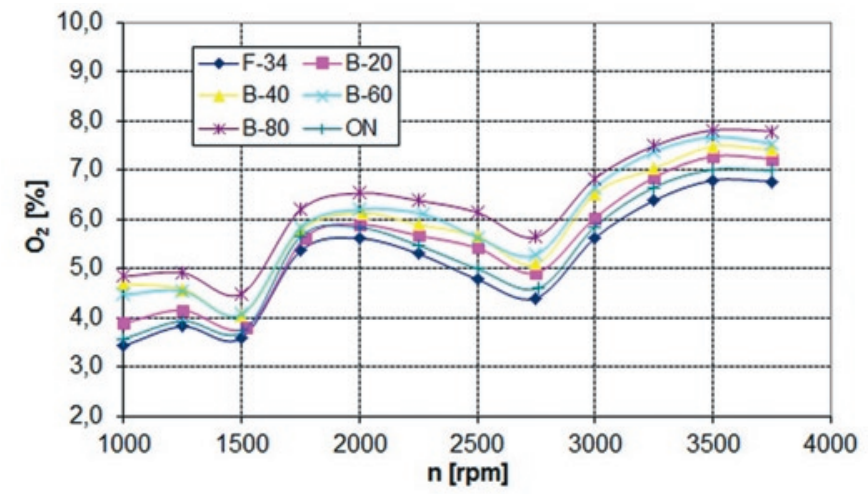

d)

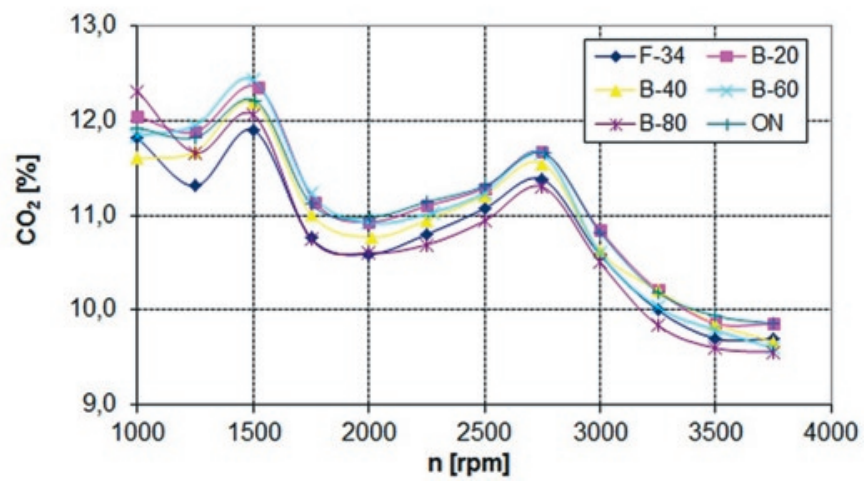

Fig. 3. External characteristic of the engine: a) concentration of carbon monoxide in exhaust, b) concentration of oxygen in exhaust, c) concentration of hydrocarbons in exhaust, d) concentration of carbon dioxide in exhaust 
cated parameters, concentration of toxic components and smoke in exhaust gases.

Based on the analysis of measured external characteristics of the G9T engine fuelled with different kind of fuels it has to be said, that the biggest effective power of the engine is reached when it is fuelled with basic fuel (ON) (fig. 1a and 1b). The Usage of the F-34 fuel caused a little diminish of effective power $\left(\mathrm{N}_{\mathrm{e}}\right)$ ca. $(1 \div 2) \%$. The RME addition to the F-34 fuel caused next diminish of effective power ca. $(7 \div 8) \%$, depending on F-34/RME mixture ratio (percent ratio of ester). The reason of it is increasing of F-34/RME mixture density and diminishing of a heat value. Differences in effective power increase due to rotated speed of the engine.

The least fuel consumption is reached for diesel oil (fig. 1.c), which is the basic fuel, although values for F-34 fuel are very similar. Using RME in fuel mixtures caused increasing of fuel consumption $\left(\mathrm{G}_{\mathrm{e}}\right)$ ca. $(3 \div 5) \%$ depending on F-34/RME ratio and rotated speed of the engine. It is caused by lesser heat value of the mixture and necessity of delivering more fuel to the cylinder to reach the same effective power.

The least specific fuel consumption value was observed for the F-34 fuel (similar values for ON) (fig. 1.d), which are $233 \mathrm{~g} /\left(\mathrm{kW}^{*} \mathrm{~h}\right)$ and $236 \mathrm{~g} /\left(\mathrm{kW}^{*} \mathrm{~h}\right)$ respectively with rotational speed $\mathrm{n}=1500 \mathrm{rpm}$. Higher specific fuel consumption is caused by smaller heat value and bigger viscosity of RME. Bigger viscosity influenced on worse spraying and bigger heterogeneity of fuel stream. It caused incomplete combustion of air/fuel mixture.

The positive effect of F-34/RME mixtures' influence on emission of smoke was observed (fig. 2.a). The biggest amount of smoke was observed when the engine was fuelled with F-34 (similar values was for $\mathrm{ON}$ ), although with mixtures with of increased ratio of esters smoke is almost $2 \ldots 3$ times lesser. This trend is observed in whole range of the engine rotational speed. A littlelater beginning of injection caused strong growth of smoke emission when the engine is fuelled with diesel oil. Diminish of smoke emission is caused by lesser effective power as well.

Temperature of exhaust gases on outlet tube is the highest when the engine is fuelled with $\mathrm{ON}$ and reaches $620^{\circ} \mathrm{C}$ with $\mathrm{n}=1500 \mathrm{rpm}$ (fig. 2b). The lowest temperature ca. $592^{\circ} \mathrm{C}$ of exhaust gases was observed with mixture $\mathrm{B}-80$ with $\mathrm{n}=1500 \mathrm{rpm}$, it can be observed diminish of temperature of more than $45^{\circ} \mathrm{C}$. There is observed that with increasing RME ratio in fuel mixture temperature of exhaust is lower.

The lowest value of air/fuel ratio coefficient $\lambda$ is observed when fuelling with F-34 fuel (fig. 2.c). Esters additives evidently increases $\lambda$ coefficient. In case of B- 80 mixture it increases ca. $25 \%$. This is caused by bigger amount of oxygen in RME molecule and lesser need for oxygen during combustion.

Concentration of nitrogen oxides in exhaust gases is the lowest for F-34 and ON fuels in all range of rotational speed (fig. 2.d). During fuelling with RME fuel mixtures it is observed that nitrogen oxides emission is increasing ca. $(10 \div 15) \%$. It is caused by bigger amount of oxygen in RME molecule. Additionally that fuel has bigger aptitude to autoignition (bigger cetan value). It causes change in combustion process. Local temperature inside cylinder increases and causes increasing of nitrogen oxides emission. Concentration of nitrogen oxides is the lowest for F-34 and $\mathrm{ON}$ in all range of rotational speed of the engine. During fuelling with F-34/RME mixtures increasing of this component concentration ca. $(10 \div 15) \%$ is observed

While rotational speed is low big concentration of carbon monoxide is observed. Increasing speed causes significant diminish of carbon monoxide concentration. The biggest concentration is observed during fuelling the engine with F-34. Mixture with RME caused diminish of its concentration in range of high speed of the engine ca. $(10 \div 15) \%$ (fig. 3.a). Lower concentration of carbon monoxide in exhaust during fuelling of the engine with F-34/RME mixture testifies about changing of combustion process in compare to pure F-34 and $\mathrm{ON}$. RME additives positively influenced on carbon monoxide concentration in range of low speed of the engine. When rotational speed is above $1500 \mathrm{rpm}$ it is on the same level, without regard on used kind of fuel.

Concentration of oxygen is very similar as $\lambda$ coefficient. The lowest value is seen during fuelling with F-34 and ON. The biggest during fuelling with B-80 - increasing reach ca. $(20 \div 25) \%$ (fig. 3.b).

Concentration of hydrocarbons in exhaust gases is about $50 \%$ lower when fuelling with B-80 mixture for all range of the engine speed (fig. 3.c). Lower concentration of hydrocarbons in exhaust is a result of higher concentration of oxygen in air/fuel mixture as it was in case of carbon monoxide. It can be seen on fig. 4. Concentration of carbon dioxide is opposite to oxygen concentration. The lowest value is observed for F-34 fuel and the highest (ca. $(6 \div 10) \%$ for F-34/RME mixtures (fig. 3.d).

\subsection{Load characteristics}

Load characteristics were done in range speed $1500 \div 3000 \mathrm{rpm}$ with $500 \mathrm{rpm}$ step. In the paper there characteristics with rotated speed $\mathrm{n}=1500 \mathrm{rpm}$ (range of maximum torque speed $\mathrm{M}_{\mathrm{omax}}$ ) and $\mathrm{n}=2500 \mathrm{rpm}$ (range of maximum effective power $\mathrm{N}_{\mathrm{emax}}$ ) are discussed. In this example there was evaluated influence of used fuel and its ecological characteristics. Range of changes is different for all parameters.

The lowest specific fuel consumption is observed during fuelling the engine with F-34 and ON fuels. In range of $n=1500 \mathrm{rpm}$ it is equal ca. $225 \mathrm{~g} /\left(\mathrm{kW}^{*} \mathrm{~h}\right)\left(227 \mathrm{~g} /\left(\mathrm{kW}^{*} \mathrm{~h}\right)\right.$ with $\left.\mathrm{ON}\right)$ with load

$\mathrm{M}_{\mathrm{o}}=180 \mathrm{~N}^{*} \mathrm{~m}$. Addition of RME to F-34 fuel caused increasing of specific fuel consumption. In dependency of F-34/RME ratio this change is equal $(6 \div 16 \%)$ (fig. $4 . a)$. It is caused by lower heat value and higher density of RME. During investigation with lower load value of specific fuel consumption was lower with F-34 and ON then with RME mixtures. It was probably caused by lower temperature in combustion chamber of the engine and worse condition to fuel evaporation. Opposite situation is observed with high load of the engine when combustion intensity is increased because of addition of oxygen from RME molecules.

Having fuel consumption changes analysed it can be said that the lowest values were observed for F-34 and ON fuels. It was $3,66 \mathrm{~kg} / \mathrm{h}$ and $3,76 \mathrm{~kg} / \mathrm{h}$ (for $\mathrm{n}=1500 \mathrm{rpm}$ ) as well as $7,77 \mathrm{~kg} / \mathrm{h}$ and $8,00 \mathrm{~kg} / \mathrm{h}$ (for $\mathrm{n}=2500 \mathrm{rpm}$ ). Fuel consumption increasing ca. $(10 \div 12) \%$ (fig. $4 \mathrm{~b})$ going after increasing of RME ratio in fuel mixture. It is caused by diminish of mixtures heat value and compensation by increasing mass of fuel used for keeping the same level of load and speed of the engine. Increasing of fuel consumption may be caused by increasing of viscosity and worse spraying, vaporing and burning of fuel in the engine.

Addition of RME to F-34 fuel caused significant diminish of smoke emission. It influenced on ecological properties of the engine significantly. When $n=1500 \mathrm{rpm}$ smoke emission is 2 times lower (fig. 5.a) with fuelling of B80 fuel.

Air/fuel coefficient $\lambda$ is the lowest when load is maximum with $\mathrm{n}=1500 \mathrm{rpm}$ as well as $\mathrm{n}=2500 \mathrm{rpm}$. Lower values were observed with fuelling by F-34 and $\mathrm{ON}$ and the highest with fuelling of B80 mixture (increasing reach ca. 5\%). This is caused by highest concentration of oxygen in RME and lower need for oxygen during combustion in the engine chamber.

The lowest concentration of nitrogen oxides in exhaust gases is observed for F-34 and ON fuels in all range of load (fig. 5.d). During fuelling with F-34/RME mixtures nitrogen oxides concentration increasing ca. $(10 \div 15) \%$. It is caused by presence of oxygen in RME. Moreover this fuel has higher tendency for autoignition (bigger cetan number). It influence on combustion process by increasing the temperature inside cylinder and increasing of nitrogen oxides concentration.

High concentration of carbon monoxide is observed with low and medium load of the engine, for speed $n=1500 \mathrm{rpm}$ and $n=2500 \mathrm{rpm}$ 
a)

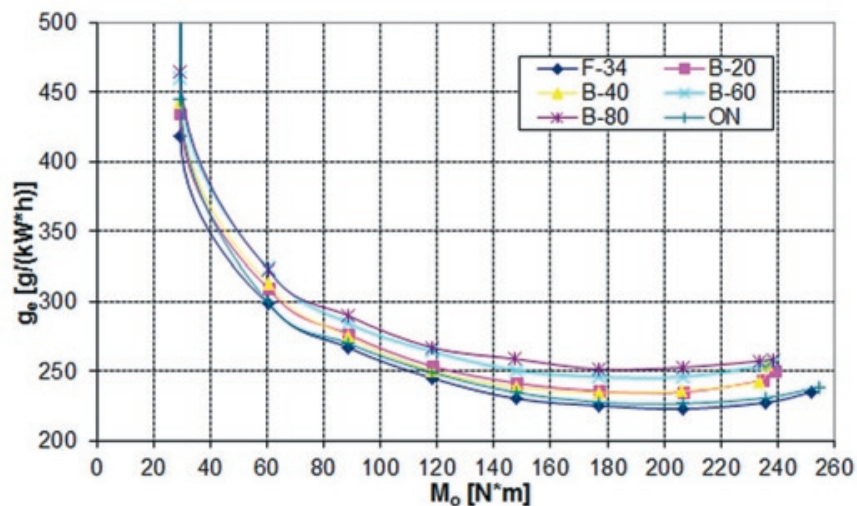

b)

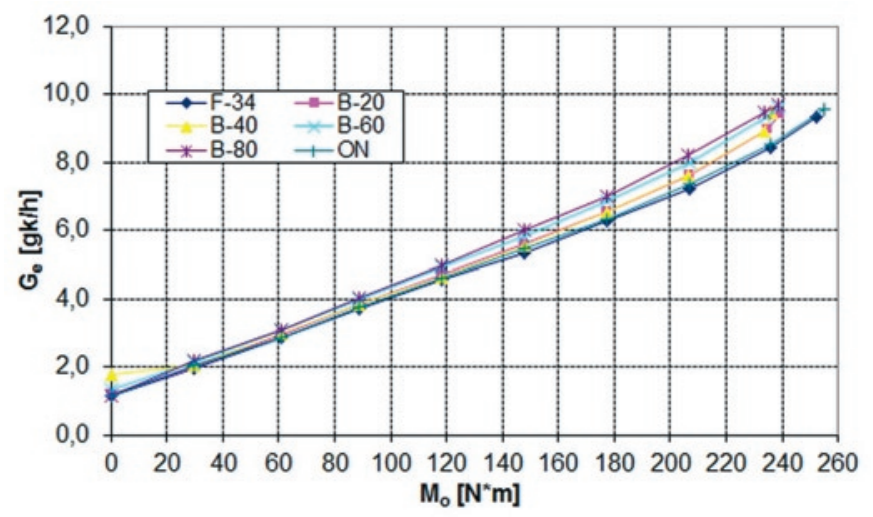

Fig. 4. Load characteristic of the engine, $n=1500 \mathrm{rpm}$ : a) specific fuel consumption, b) fuel consumption

a)

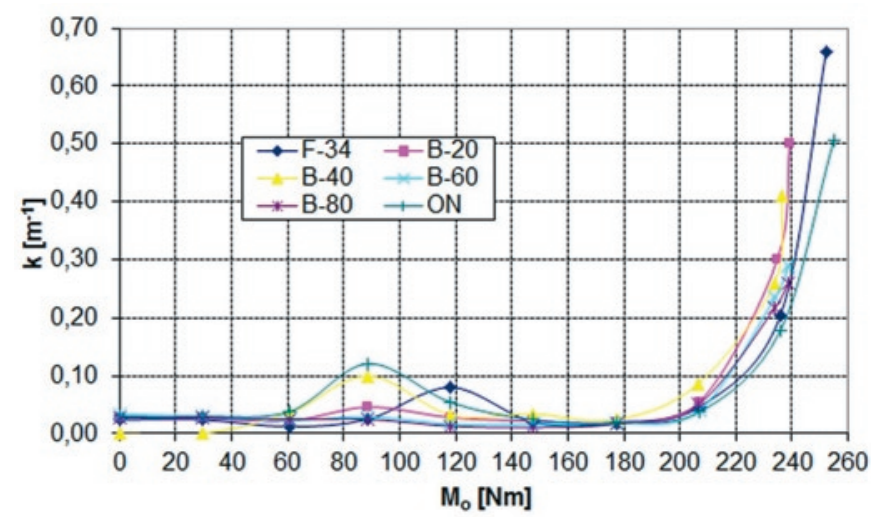

c)

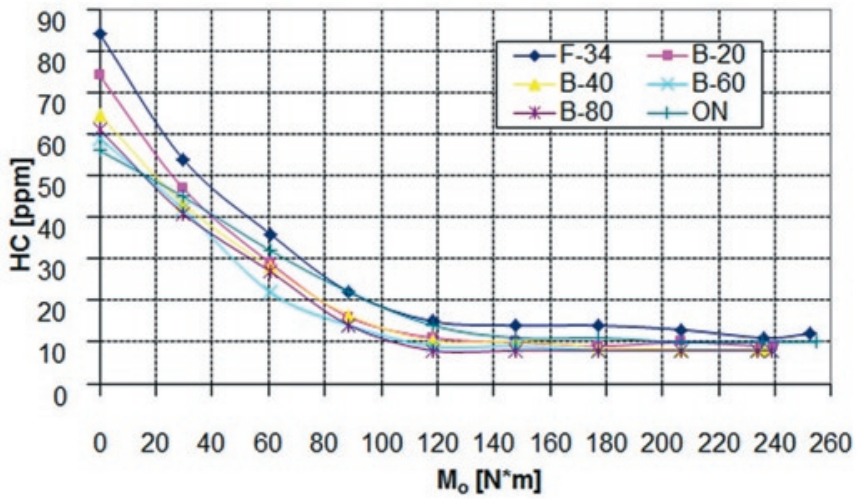

b)

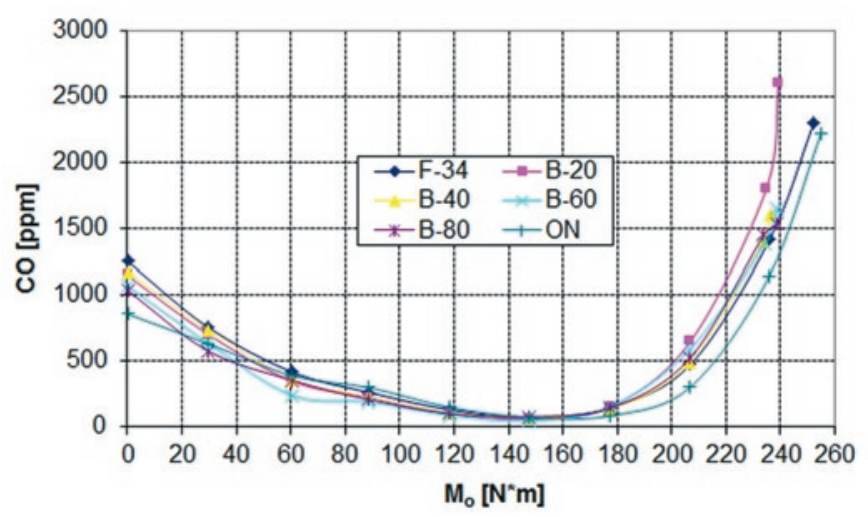

d)

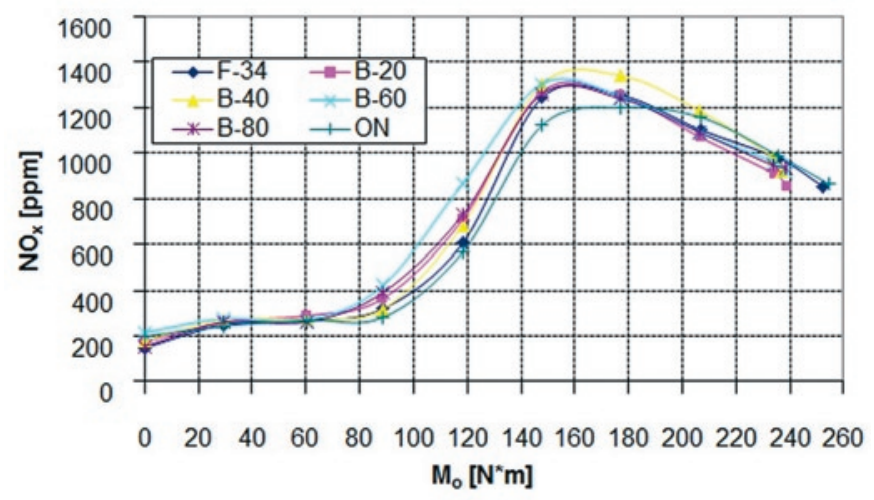

Fig. 5. Load characteristic of the engine, $n=1500 \mathrm{rpm}$ : a) extinction coefficient of absorbed radiation, b) concentration of carbon monoxides in exhaust, c) concentration of hydrocarbons in exhaust, d) concentration of nitrogen oxides in exhaust

a)

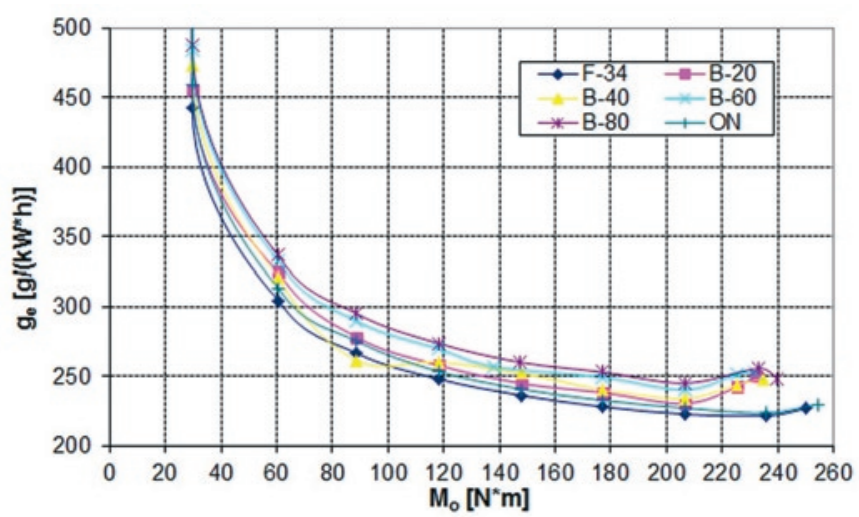

b)

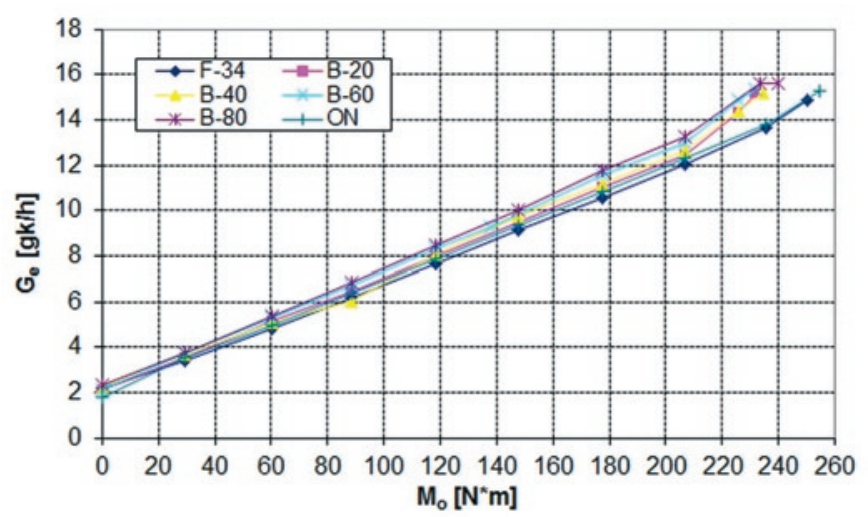

Fig. 6. Load characteristic of the engine, $n=2500$ rpm: a) specific fuel consumption, b) fuel consumption 
a)

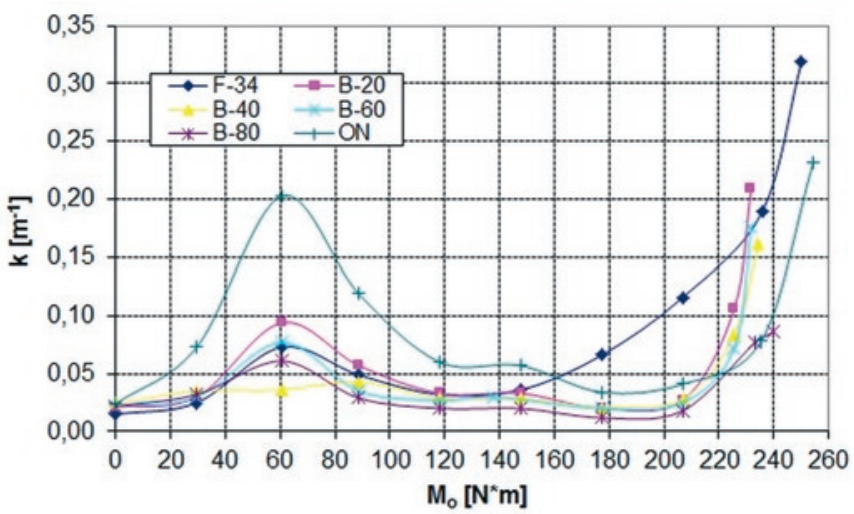

c)

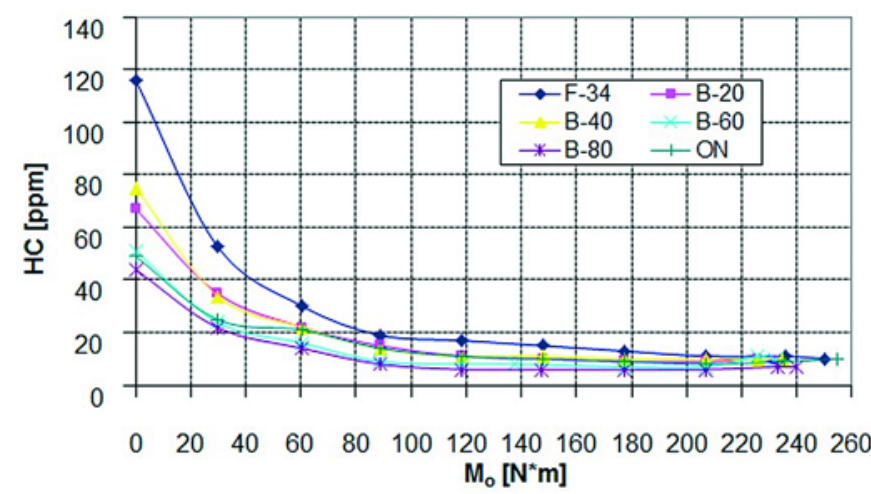

b)

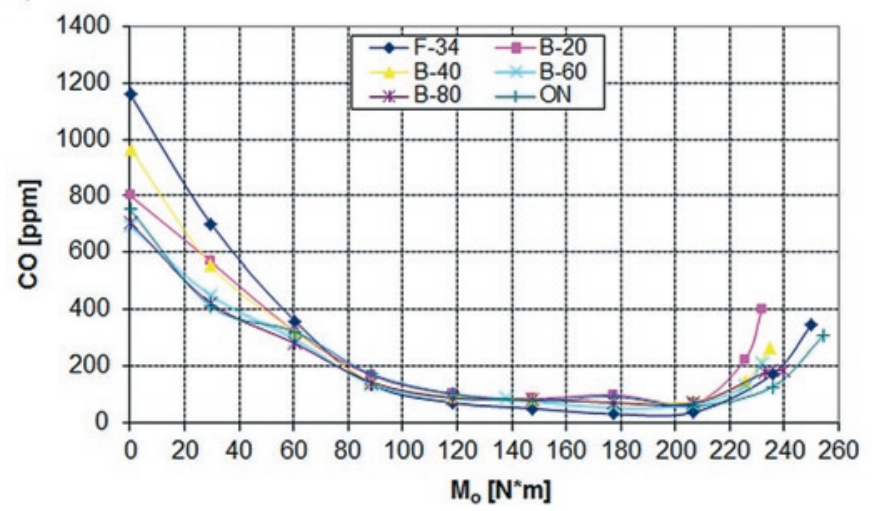

d)

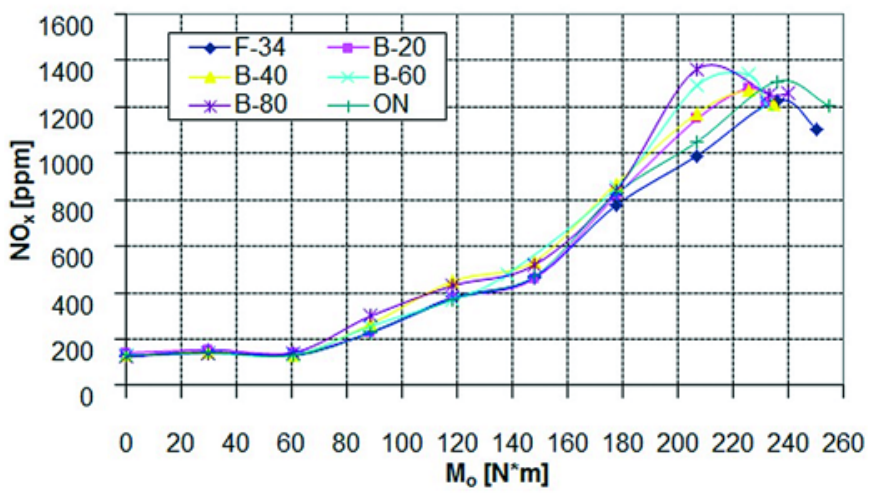

Fig. 7. Load characteristic of the engine, $n=2500 \mathrm{rpm}$ : a) extinction coefficient of absorbed radiation, b) concentration of carbon monoxides in exhaust, c) concentration of hydrocarbons in exhaust, d) concentration of nitrogen oxides in exhaust.

as well. In range of medium value of torque concentration of carbon monoxide is persisting on low level. The highest concentration of carbon monoxide occurs during fuelling with F-34 and ON fuels. Ester additives to basic fuels persisted ca. 2 times less concentration of carbon monoxide in exhaust with speed $n=1500 \mathrm{rpm}$ (fig. 5.b). Lower concentration of carbon monoxide during fuelling the engine with mixture of basic fuel and bio component evidences about better combustion in compare to basic fuels F-34 and ON.

Concentration of hydrocarbons in exhaust gases is lower ca. $(50 \div 60) \%$ during fuelling with RME mixture than with F-34 fuel (with speed $n=1500 \mathrm{rpm}$ and $\mathrm{n}=2500 \mathrm{rpm}$ ) in all range of load. In the same way as carbon monoxide lower concentration of hydrocarbons with ester additives in exhaust gases is a result of its better combustion.

a)

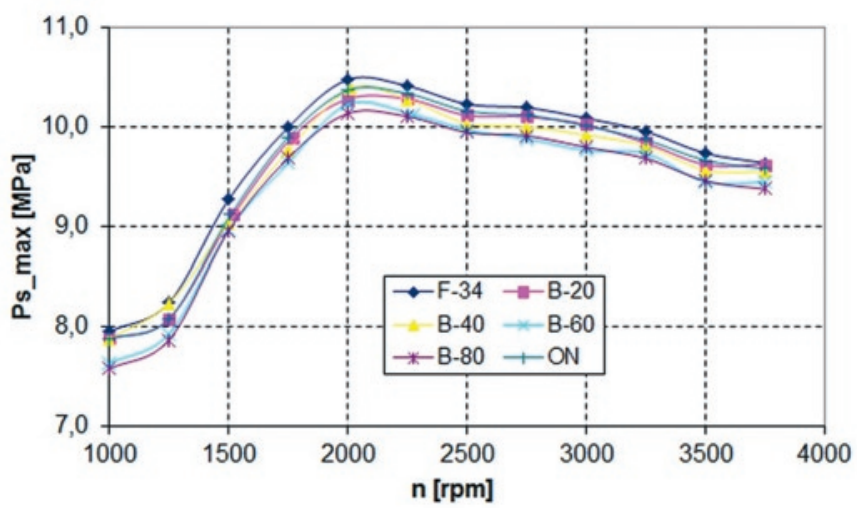

\subsection{Influence of F-34 and RME mixture on working param- eters of the engine}

Analysis of combustion process in the G9T engine combustion chamber was carried on the basis of the engine working cycles investigation. During investigation several dozen of combustion processes cycles were saved, and next 10 of them were statistically recalculated and characteristic parameters of combustion process were found. The maximum value of pressure and angle of auto-ignition delay are shown on graphs. The angle of auto-ignition delay is appointed as a difference between start of an injector needle lift and start of an active combustion in the engine chamber.

Significant differences are seen on line of maximum pressure in the combustion chamber. The highest values of pressure were measured on F-34 and ON fuels. This values are similar but a little bit

b)

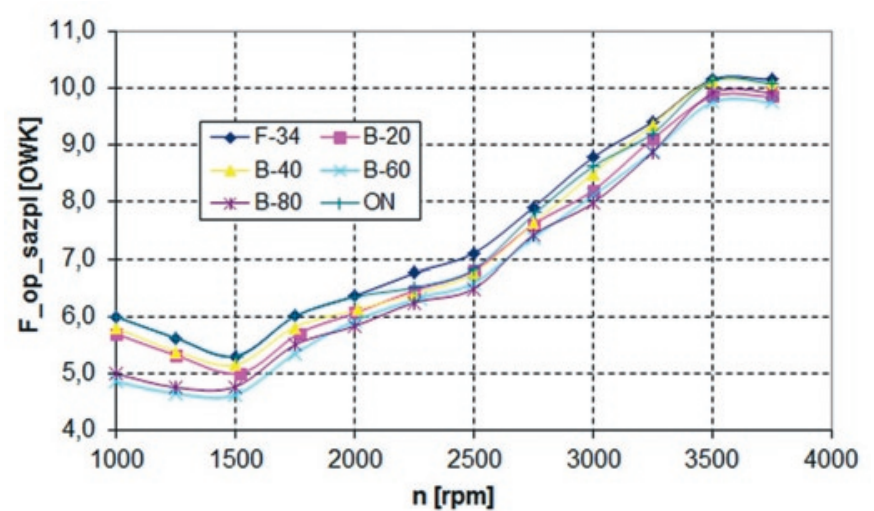

Fig. 8. External characteristic of the engine: a) maximum combustion pressure, b) angle of auto-ignition delay 
a)

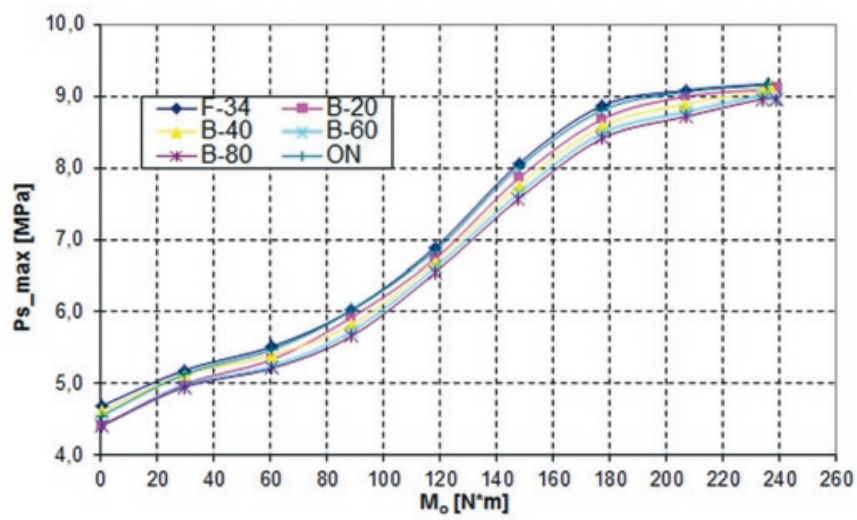

b)

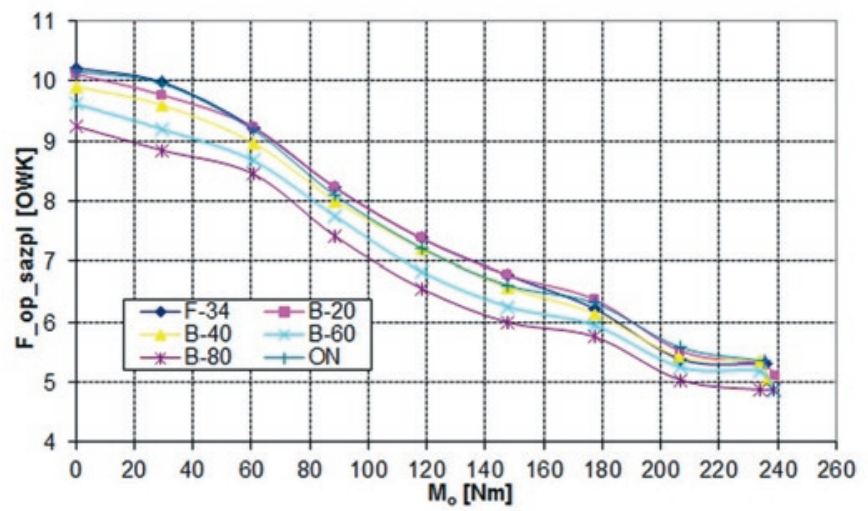

Fig. 9. Load characteristic of the engine, $n=1500$ rpm: a) maximum combustion pressure, b) angle of auto-ignition delay

higher in case of F-34 fuelling. This differences are no higher than 0.1 $\mathrm{MPa}$ (fig. 8.a). When mass ratio of RME increasing in a fuel mixture the diminish of maximum pressure value in the chamber is observed. The lowest values were observed for B80 mixture. Differences between maximum value for $\mathrm{F}-34$ and $\mathrm{ON}$ fuels and minimum value for B80 mixture were ca. $0.4 \mathrm{MPa}$ in almost all range of rotational speed of the engine. The reason of such high decrease of pressure value is the lower dose of energy (lower heat value of fuel mixtures) consisted in fuel dose injected to the combustion chamber as well as longer time of injection. It causes slower heat transfer and diminish of peak values of combustion pressure.

After analysing the influence of RME ratio in F-34 fuel on the angle of auto-ignition delay (fig. 8.b) it is seen, that increasing of RME ratio causes shortening of angle of auto-ignition delay. The lowest values of angle of auto-ignition delay were observed for B80 mixture, and the highest were for F-34 fuel. For rotational speed $n=1000$ $\mathrm{rpm}$ difference is ca. $1^{\circ}$ of crank shaft rotation (CSR) and it decreases with the increase of rotational speed. For speed $n=3500 \mathrm{rpm}$ is equal $0.2^{\circ} \mathrm{CSR}$. Shortening of angle of auto-ignition delay for B80 fuel mixture is caused by lower temperature of auto-ignition as well as oxygen ratio in RME, which influence on speeding up of fuel oxidation.

Similar coincidences may be observed during analyse of load characteristics of the engine. While increasing of ester mass ratio in F-34/RME mixtures the diminish of maximum pressure value in the combustion chamber is observed. The lowest values were measured for B80 fuel mixture. Differences between maximum value for F-34 fuel and minimum value for B80 mixture were ca. 0.4 MPa in all range of the engine load. The reason for that decreasing of maximum pressure value is the longest time of injection of the single dose of fuel needed for creation the adequate torque $[8,11]$.

The opposite phenomenon may be observed during the analysis of load influence on the angle of auto-ignition delay. The highest differences are observed for the lowest load of the engine (fig. 9.b) and it reaches ca. $1{ }^{\circ} \mathrm{CSR}$. With the increase of load that angle diminishes to the level of ca. $0,5^{\circ} \mathrm{CSR}$. It is caused by increasing of injection pressure $[5,8,11]$. Fuel injection pressure increase causes better spraying of fuel, the increase of fuel string range and improve homogeneity of air /fuel mixture. It shortens the angle of auto-ignition delay as well.

\section{Conclusion}

The usage of unconventional fuels for fuelling of military vehicle engines nowadays is a wide disputed problem. The numerous investigations about adaptation of renewable fuels for fuelling of self-ignited engines (diesels) are lead. The best matches for fuelling diesel engines are methyl esters of fatty acids. In Poland they are acquired with processing of rapeseed oil (RME). It is a method to diminish the oil import. Using fuels based on RME is also beneficial for agricultural development.

The paper contains the results of investigation showing the influence of F-34/RME mixtures on a diesel engine work. The engine was equipped with the Common Rail fuelling system. As results of investigation there were ascertained, that with increasing of RME ratio in F-34 fuel diminish concentration of carbon monoxide and hydrocarbons in exhaust is observed. It is caused by the increasing of oxygen ratio in F-34/RME mixture (oxygen from ester molecule). On the other hand the concentration of nitrogen oxides and oxygen in exhaust increased. This change is proportional to RME ratio in F-34 fuel. This phenomenon is caused by increasing of density and viscosity of fuel mixture. It is connected to slower fuel flow by tubes and injector holes in fuelling system in compare to pure F-34 or ON flow.

As the result of investigation it was ascertained that the G9T Renault engine parameters equipped with the Common Rail system fuelled with F-34/RME mixtures changed in comparison to standard F-34 or ON fuels.

On the basis of the research it is to be said that:

- the diminish of the engine effective power reaches $15 \%$ (depending of the engine work condition or used fuel mixture), during fuelling with F-34/RME mixtures,

- in comparison to F-34 and ON fuels, lower effective power of the engine is connected with lower heat value of RME,

- specific fuel consumption is 15\% higher for F-34/RME mixtures especially in ranges of high speed and load of the engine,

- RME addition to F-34 beneficially influences on smoke (soot) and particulate matters (PM) emissions; smoke emission may be up to 3 times lower in comparison to the engine fuelled with diesel oil $(\mathrm{ON})$,

- using RME as additives for F-34 fuel causes the diminish of carbon monoxide concentration up to $15 \%$ especially in range of low values of rotational speed and load of the engine,

- increasing of oxygen ratio in exhaust gases of ca. $25 \%$ is caused by presence of oxygen in RME molecule,

- hydrocarbons concentration in exhaust gases is lower up to $50 \%$ during fuelling the engine F-34/RME mixture.

The investigation about unconventional fuels application contributes to its introduction to mass production. Leading that investigation is crucial because it lets us to evaluate the influence of fuel composition on engine's work in different load and speed condition. 


\section{References}

1. Ambrozik A, Kruczyński S, Jakubiec J, Orliński S. Wpływ zasilania silnika spalinowego o zapłonie samoczynnym paliwem mineralnym i roślinnym na proces wtrysku oraz rozpad strugi paliwa. Journal of KONES Powertrain and Transport 2006; 3(13): 21-28.

2. Baczewski K, Kałdoński T, Walentynowicz J. Sprawozdanie z realizacji pracy naukowo-badawczej. Opracowanie koncepcji wdrożenia jednolitego paliwa do lotniczych silników turbinowych i silników wysokoprężnych. Warszawa: Wojskowa Akademia Techniczna, 2001.

3. Baczewski K, Kałdoński T. Paliwa do silników o zapłonie samoczynnym. Warszawa: WKŁ; 2004.

4. Brzozowski K, Nowakowski J. Toxicity of exhaust gases of compression ignition engine under conditions of variable load for different values of engine control parameters. Eksploatacja i Niezawodnosc - Maintenance and Reliability 2011; 4(52): 56-62.

5. Chong Ch. T, Hochgreb S. Spray flame structure of rapeseed biodiesel and Jet-A1 fuel. Fuel 2014; 115: 551-558, http://dx.doi.org/10.1016/j. fuel.2013.07.059.

6. Daisuke K, Hajime I, Yuichi G, Akira N, Yuzo A. Application of Biodiesel Fuel to Modern Diesel Engine. SAE Technical Papers; 2006-01-0233.

7. Dagaut P, Gaïl S. Chemical Kinetic Study of the Effect of a Biofuel Additive on Jet-A1 Combustion. JOURNAL OF PHYSICAL CHEMISTRY A, 2007, 111 (19): 3992-4000, http://dx.doi.org/10.1021/jp067525j.

8. Hileman J. I, Donohoo Pearl E, Stratton R. W. Energy Content and Alternative Jet Fuel Viability. Journal of Propulsion and Power 2010; 26 (6): 1184-1196.

9. Horn U, Egnell R, Johansson B, Andersson O. Detailed Heat Release Analyses With Regard To Combustion of RME and Oxygenated Fuels in an HSDI Diesel Engine. SAE Technical Papers; 2007-01-0627.

10. Karczewski M, Wilk M. Assessment of dynamic qualities of the G9T engine with common rail system, fed with battlefield-use fuel blends with a biocomponent. Journal of KONES Powertrain and Transport 2011; 1 (18): 243-252.

11. Karczewski M, Walentynowicz J, Szczęch L, Rajewski M, Pszczółkowski J. Sprawozdanie z realizacji pracy naukowo-badawczej. Określenie wpływu jednolitego paliwa F34/35 z biokomponentami na pracę wysokociśnieniowego układu zasilania typu Common Rail". Warszawa: Wojskowa Akademia Techniczna 2010.

12. Mayer A, Czerwiński J, Wyser M, Mattrel P, Heitzer A. Impact of RME/diesel blends on particle formation, particle filtration, and PAH emissions. SAE Technical Paper 2005-01-1728.

13. Osipowicz T, Abramek K. Catalytic treatment in Diesel engine injectors. Eksploatacja i Niezawodnosc - Maintenance and Reliability 2014; 16(1): 22-28.

14. Szlachta Z. Zasilanie silników wysokoprężnych paliwami rzepakowymi. Warszawa: WKŁ, 2002.

15. Zając G, Węgrzyn A. Analysis of work parameters changes of diesel engine powered with diesel fuel and FAEE blends. Eksploatacja i Niezawodnosc - Maintenance and Reliability 2008; 3: 17-24.

\section{Mirosław KARCZEWSKI \\ Leszek SZCZĘCH}

Institute of Motor Vehicles and Transportation

Faculty of Mechanical Engineering

Military University of Technology

ul. Gen. Sylwestra Kaliskiego 2, 00-908 Warszawa

E-mails: miroslaw.karczewski@wat.edu.pl, leszek.szczech@wat.edu.pl 